\title{
Biopsychosocial aspects and the complexity of care of hospitalized elderly
}

Aspectos biopsicossociais e a complexidade assistencial de idosos hospitalizados

Beatriz Aparecida Ozello Gutierrez ${ }^{1}$ Henrique Salmazo da Silva ${ }^{2}$ Helena Eri Shimizu ${ }^{3}$

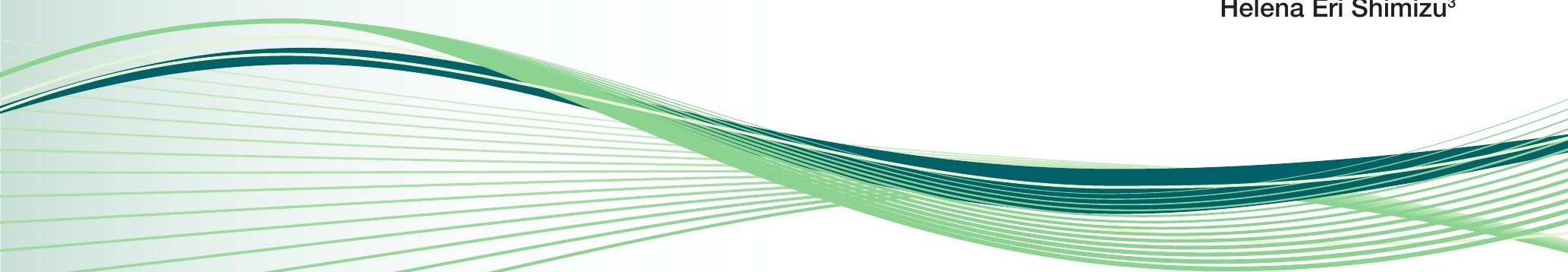

Keywords

Nursing care; Geriatric nursing; Nursing service, Hospital; Aged

Descritores

Cuidados de Enfermagem; Enfermagem geriátrica; Serviço Hospitalar de Enfermagem; Hospital; Idoso

\section{Submitted \\ 27 February 2014 \\ Accepted \\ 29 July 2014}

\section{Corresponding author}

Beatriz Aparecida Ozello Gutierrez

Arlindo Béttio Avenue, 1000, São Paulo,

SP, Brazil. Zip Code: 03828-000

biagutierrez@yahoo.com.br

DOI

http://dx.doi.org/10.1590/1982-

0194201400071

\section{Abstract}

Objective: To investigate the biopsychosocial aspects and aspects of the health system of hospitalized elderly and to classify their degree of care complexity.

Methods: This was a quantitative study whose convenience sample consisted of 279 elderly. The Interdisciplinary Medicine Instrument (INTERMED) method was used, a tool that identified biopsychosocial aspects and conditions of the health system and classified the complexity of the patient. The data were submitted to descriptive analysis.

Results: The prevailing profile was of elderly women, retired, white, with low educational levels, married and satisfied with their life conditions. The mean age was 72.3 years. The biological domain was the most compromised. As for the complexity of care, $34.8 \%$ of the patients required multiprofessional care.

Conclusion: The elderly had high care complexity, with the biological and health system domains being the most compromised.

\section{Resumo}

Objetivos: Conhecer os aspectos biopsicossociais e as condições do sistema de saúde de idosos hospitalizados e classificar o grau de complexidade assistencial.

Métodos: Trata-se de estudo quantitativo, cuja amostra por conveniência foi constituída por 279 idosos. Utilizou-se o método Interdisciplinary Medicine Instrument (INTERMED), ferramenta que identifica aspectos biopsicossociais e condições do sistema de saúde e classifica a complexidade do paciente. Os dados foram submetidos à análise descritiva.

Resultados: Predominou idosos do gênero feminino, aposentados, de cor branca, baixa escolaridade, casados e satisfeitos com as condições de saúde. A média de idade foi 72,3 anos. 0 domínio biológico foi 0 mais comprometido. Quanto à complexidade assistencial, 34,8 \% dos pacientes requerem assistência multiprofissional.

Conclusão: Os idosos apresentaram elevada complexidade assistencial, com maior comprometimento nos domínios biológico e sistema de saúde.

'Escola de Artes, Ciências e Humanidades, Universidade de São Paulo, São Paulo, SP, Brazil.

²Faculdade de Saúde Pública, Universidade de São Paulo, São Paulo, SP, Brazil.

UUniversidade Federal de Brasília, Brasília, DF, Brazil.

Conflicts of interest: there are no conflicts of interest to declare. 


\section{Introduction}

The management of elderly care has been the subject of discussions between professionals, managers and researchers in the field of aging. The literature indicates that the elderly, especially the oldest and most dependent, require long-term care and assessment of their biopsychosocial needs in the short, medium and long term, in order to prevent adverse health outcomes: falls, insufficient care, disability, institutionalization, recurrent hospitalizations, and death. ${ }^{(1-3)}$

In the last two decades, some researchers have conducted studies in order to identify aggravating factors in the health/disease status of the hospitalized patients, to improve the quality of care provided to them and also to reduce costs. ${ }^{(4-6)}$

In this context, one of the proposals that can be a tool to improve communication within the interdisciplinary team, and to characterize the complexity of care for clinical, scientific and educational purposes, is the Interdisciplinary Medicine Instrument (INTERMED): a tool that can offer positive responses in assessing patients requiring care, and in helping adjust the provision of health services in general, and in mental health. ${ }^{(7)}$ The validity of this instrument is documented for the care of several types of patients. ${ }^{(8-10)}$

Compared with usual care, targeted nursing interventions based on the INTERMED scores resulted in improvements in quality of life, at the time of admission and discharge in patients in general practice and in elderly patients requiring interdisciplinary care. ${ }^{(6,8-11)}$

Assuming the importance of providing comprehensive care to the hospitalized elderly, this study aims to investigate biopsychosocial aspects of hospitalized elderly, and aspects of the health system, and to classify their degree of care complexity.

\section{Methods}

This was a quantitative, descriptive, cross-sectional study performed in the medical clinic at the University Hospital, São Paulo University, São Paulo state, in southeastern Brazil.
The population consisted of elderly patients admitted to the unit who met the following inclusion criteria: age 60 years or older, ability to understand and respond to the interview at the time of data collection. The convenience sample consisted of 279 elderly.

For participant characterization, demographic data were investigated (name, gender, age, occupation, ethnicity, income, marital status and family life), as well as one question related to the assessment of self-perceived health status.

For data collection, the INTERMED method was used, a tool based on data from medical records and on a semi-structured interview with the patient, which is designed by an analysis of data on the biological aspects, information on care related to psychosocial aspects, and on the health system. ${ }^{(7)}$

This method classified the data into four domains related to biopsychosocial aspects and to the system used for health care/disease. Each domain had five variables related to "history", "current state" and "prognosis". The resulting twenty variables were classified from 0 to 3 . The sum of these variables resulted in a score that could range from 0 to 60 , indicating the complexity of patient care. ${ }^{(7)}$

In this study, patients were classified through INTERMED as "complex" and "non-complex" based on a cutoff point of 20 representing the need for integrated treatment. ${ }^{(10,11)}$

The INTERMED had advantages over other instruments because it was quick to administer, with an average duration between 15 and 20 minutes. It explored many pieces of patient data, providing knowledge and current, historical, and future assessment of four aspects - biological, psychological, social and health system - and enabled the collection of data by others involved in patient care, such as family members and caregivers, in cases in which the patient was unable to answer questions due to severe cognitive impairment or other disorders. ${ }^{(6,9)}$

Data were analyzed using the Statistical Package for the Social Sciences (SPSS) for Windows version 17. A descriptive analysis was performed.

The development of the study met the national and international standards of ethics in research involving human beings. 


\section{Results}

The sociodemographic profile of the 279 elderly is presented in table 1 . Most participants were female, married, Caucasian, and claimed a religion. The average age was 72.3 years. The sample was concentrated in the lower classes of education and income. More than half claimed to be retired. Family income was one to three times the minimum wage. As for the spiritual aspects, most claimed to have a religion and considered having it to be very important. In relation to family life, $31.2 \%$ lived with their spouses. The results revealed that most elderly considered their health status compromised.

The INTERMED variables shown in table 2 indicate higher scores on the biological domain variable "chronicity", because $60.9 \%$ of participants had more than one chronic disease, and on the variable "organization of care" in the health care system domain, because $94.3 \%$ the elderly did not have a perspective of discharge at the time of interview. Also, in the health care system domain, $36.2 \%$ of the elderly were at risk for impediments to health care.

Table 3 shows that the biological domain is the most compromised and, also, that the total INTERMED score, a value that characterizes the complexity of patient care, ranged from 3 to 43 . The mean total INTERMED score was 18.13.

Table 1. Sociodemographic profile of hospitalized elderly

\begin{tabular}{lc}
\hline Variable & $\mathrm{n}(\%)$ \\
\hline Gender & \\
Female & $151(54.1)$ \\
Male & $128(45.9)$ \\
Total & $279(100)$ \\
Ethnicity (stated) & \\
White & $181(65)$ \\
Black & $46(16.4)$ \\
Brown & $49(17.5)$ \\
Asian & $3(1.1)$ \\
Education & \\
\hline
\end{tabular}

continuation

\begin{tabular}{|c|c|}
\hline Variable & $\mathrm{n}(\%)$ \\
\hline 0 years & $59(21.1)$ \\
\hline 1 to 4 years & $167(59.7)$ \\
\hline 5 to 8 years & $18(6.5)$ \\
\hline 9 to 11 years & $18(6.5)$ \\
\hline 12 to 15 years & $17(6.2)$ \\
\hline \multicolumn{2}{|l|}{ Marital status } \\
\hline Married & $124(44.4)$ \\
\hline Single & $97(34.8)$ \\
\hline Widow(er) & $26(9.3)$ \\
\hline Divorced & $25(9.0)$ \\
\hline Stable union & $7(2.5)$ \\
\hline \multicolumn{2}{|l|}{ Occupation } \\
\hline Retired & $178(63.8)$ \\
\hline Pensioner & $34(12.2)$ \\
\hline Worked & $30(10.8)$ \\
\hline Neither worked nor was retired & $37(13.2)$ \\
\hline \multicolumn{2}{|l|}{ Family income } \\
\hline$<1$ Minimum wage & 102(36.6) \\
\hline 1 - 3 Minimum wage & $129(46.2)$ \\
\hline 3,5 - 5 Minimum wage & $26(9.3)$ \\
\hline$>5$ Minimum wage & $22(7.9)$ \\
\hline \multicolumn{2}{|l|}{ Religion } \\
\hline \multicolumn{2}{|l|}{ Claimed a religion } \\
\hline No & $25(9)$ \\
\hline Yes & 254(91) \\
\hline \multicolumn{2}{|l|}{ Degree of importance } \\
\hline Very important & $216(77.1)$ \\
\hline Fairly important & $39(14.2)$ \\
\hline A little important & $24(8.7)$ \\
\hline \multicolumn{2}{|l|}{ Lived } \\
\hline Alone & $52(18.6)$ \\
\hline With spouse & $87(31.2)$ \\
\hline With children & $50(17.9)$ \\
\hline With grandchildren & $3(1.1)$ \\
\hline With spouse and others & $45(16.1)$ \\
\hline With children and grandchildren & $34(12.2)$ \\
\hline Others & $8(2.9)$ \\
\hline \multicolumn{2}{|l|}{ Self-health perception } \\
\hline Good & $135(48.6)$ \\
\hline Fair & $104(37.4)$ \\
\hline $\mathrm{Bad}$ & $39(14)$ \\
\hline
\end{tabular}


Table 2. Score of the variables in the biological, psychological and health care system domains

\begin{tabular}{|c|c|c|c|c|}
\hline \multirow{2}{*}{ Variables } & \multicolumn{2}{|c|}{ Score } & \multicolumn{2}{|c|}{ Score } \\
\hline & $\mathrm{n}(\%)$ & $\mathrm{n}(\%)$ & $\mathrm{n}(\%)$ & $\mathrm{n}(\%)$ \\
\hline Biological domain & 0 & 1 & 2 & 3 \\
\hline \multicolumn{5}{|l|}{ History } \\
\hline Chronicity & $21(7.5)$ & $20(7.2)$ & $68(24.4)$ & 170(60.9) \\
\hline Diagnostic dilemma & $78(28)$ & $131(47)$ & $55(19.7)$ & $15(5.3)$ \\
\hline \multicolumn{5}{|l|}{ Current state } \\
\hline Severity of symptoms / Compromising & $5(1.8)$ & 62(22.2) & $162(58.1)$ & $50(17.9)$ \\
\hline Diagnostic / Therapeutic challenge & $42(15.1)$ & $161(57.7)$ & 68(24.4) & $8(2.8)$ \\
\hline \multicolumn{5}{|l|}{ Prognoses } \\
\hline Complications and life-threat & $16(5.7)$ & 102(36.6) & $113(40.5)$ & $48(17.2)$ \\
\hline Psychological domain & 0 & 1 & 2 & 3 \\
\hline \multicolumn{5}{|l|}{ History } \\
\hline Restrictions in coping & 176(63.1) & $69(24.7)$ & $22(7.9)$ & $12(4.3)$ \\
\hline Psychiatric dysfunction & 195(69.9) & $54(19.4)$ & $28(10)$ & $2(0.7)$ \\
\hline \multicolumn{5}{|l|}{ Current state } \\
\hline Resistance to treatment & $236(84.6)$ & $31(11.1)$ & $12(4.3)$ & $-(-)$ \\
\hline Psychiatric symptoms & $159(57)$ & $54(19.4)$ & $60(21.5)$ & $6(2.1)$ \\
\hline \multicolumn{5}{|l|}{ Prognoses } \\
\hline Mental health threat & $143(51.2)$ & $89(31.9)$ & $42(15.1)$ & $5(1.8)$ \\
\hline Social domain & 0 & 1 & 2 & 3 \\
\hline \multicolumn{5}{|l|}{ History } \\
\hline Social vulnerability & 130(46.6) & $112(40.1)$ & $12(4.3)$ & $25(9)$ \\
\hline Social dysfunction & 185(66.3) & $59(21.1)$ & $15(5.4)$ & $20(7.2)$ \\
\hline \multicolumn{5}{|l|}{ Current state } \\
\hline Residential instability & $157(56.3)$ & $100(35.8)$ & $38(13.6)$ & $7(2.5)$ \\
\hline Restrictions of network & $164(58.8)$ & $63(22.6)$ & $16(5.7)$ & $14(5)$ \\
\hline \multicolumn{5}{|l|}{ Prognoses } \\
\hline Social vulnerability & $146(52.4)$ & 111(39.8) & $16(5.7)$ & $6(2.1)$ \\
\hline Health care system domain & 0 & 1 & 2 & 3 \\
\hline \multicolumn{5}{|l|}{ History } \\
\hline Care access & 184(65.9) & $49(17.6)$ & $13(4.7)$ & $33(11.8)$ \\
\hline Prior treatment experience & $211(75.6)$ & $42(15.1)$ & $19(6.8)$ & $7(2.5)$ \\
\hline \multicolumn{5}{|l|}{ Current state } \\
\hline Organization of care & $11(3.9)$ & $4(1.4)$ & $1(0.4)$ & 263(94.3) \\
\hline Coordination of care & 257(92.1) & $20(7.1)$ & $1(0.4)$ & $1(0.4)$ \\
\hline \multicolumn{5}{|l|}{ Prognoses } \\
\hline Impediments of the health care system / Health insurance & $178(63.8)$ & $80(28.7)$ & $12(4.3)$ & 9(3.2) \\
\hline
\end{tabular}

Table 3. Scores of the INTERMED domains

\begin{tabular}{lcccc}
\hline Domain & Mean & Standard deviation & Minimum & Maximum \\
\hline Biological & 8.17 & 2.49 & 3 & 14 \\
Psychological & 2.51 & 3.01 & 0 & 12 \\
Social & 3.04 & 3.15 & 0 & 15 \\
Health care system & 4.33 & 1.84 & 0 & 11 \\
Total & 18.13 & 7.24 & 3 & 43 \\
\hline
\end{tabular}

$\mathrm{t}$ Teste $=0$

\section{Discussion}

One limitation of this study is the prevalence bias, typical of cross-sectional studies. Another limitation is the lack of deep understanding of the subjective dimension of the factors related to the biological, psychological, social and health system domains by using a quantitative measurement instrument.
Nevertheless, although this study was cross-sectional, with a specific population of elderly patients at a teaching hospital, the indicators evaluated through INTERMED were similar to those of international studies, which confirmed the importance of the use of this instrument by the multidisciplinary team to identify the complexity of care, the social and the health care system vulnerability for the hospitalized elderly. ${ }^{(8-11)}$

The profile of the elderly investigated in this study showed a mean age of 72.3 years, females predominated, with a socioeconomic income in the range of three times the minimum wage, a profile that was similar to that observed in the literature. (12-15) The increase in longevity was a response to the evolution of medical science, however, the quality 
of life of the elderly was one of the greatest challenges in developing countries, where poverty and social inequality were highlighted. ${ }^{(16)}$

The impoverishment of the social support network, combined with a reduced economic profile and the worst objective (degree of dependence) conditions and subjective (satisfaction with their own health and living conditions) health conditions may predispose the elderly to negative health outcomes that will increase the costs in the care network, if properly planned long-term care is not implemented in its complexity and scope. ${ }^{(17)}$

It was found in this study that most elderly lived with their families (spouse, children, grandchildren), thereby their closest support consisted of the family. However, the high proportion of elderly who reported living alone in their homes drew attention, reaching $18.6 \%$ of the sample, higher than the rate described in the literature. ${ }^{(18)}$ Therefore, there is need for restructuring of health services that includes supervision of the elderly at home. ${ }^{(19)}$

It is unquestionable that the social engagement of the elderly in the family, community and social activity groups enables improvements in self-esteem and motivation for life. ${ }^{(20,21)}$

In this study, most elderly had negative perceptions of their health status, higher than the results of the Brazilian study. ${ }^{(22)}$

Several factors contributed to confirmation of such perceptions, with diseases and physical and mental losses being the main factors. The disabling signs and symptoms were expressive of body image, lower agility and strength, which contribute to the dissatisfaction with the health state. Nevertheless, some practices can improve this condition, especially the practice of physical activities and regular health care. ${ }^{(21)}$

As for the complexity of care, the mean total score was 18.13 . However, $34.8 \%$ of patients had total INTERMED scores greater than 20 points, indicating a need for integrated care. These findings were similar to one international study. ${ }^{(23)}$ It was also found that $6.1 \%$ of these patients were classified as high complexity with a score higher than 30 . There was evidence of improved health outcomes following targeted intervention for patients identified as complex through INTERMED. ${ }^{(12)}$
Thereby, it is recommended that the more complex patients are followed after hospital discharge by a multidisciplinary team that will enable comprehensive care in order to improve the biopsychosocial aspects. ${ }^{(24)}$

Moreover, coordination of care can be facilitated with the use of INTERMED, because it has been correlated with clinical outcomes of patients and their satisfaction with the care. ${ }^{(13,14)}$

The elderly in the study pointed to problems in the health system, highlighting the variable, "organization of care". These data indicated that there were difficulties in the organization of integrated care for the elderly, due to their vulnerability related to conditions resulting from the natural aging process that required multiple forms of care. Studies showed that the elderly often had multiple diseases, which could cause limitation and dependence. ${ }^{(4)}$

In this sense, it should be emphasized that health professionals must be prepared to assist the elderly in the organization of their care, with services that must be varied to meet their multiple needs. It is important to build networks of elderly care. Thus, it is noteworthy that the nurse may facilitate access to comprehensive care management programs.

Efforts have been made to improve health service usage and costs with new management models, and comprehensive health care for people with complex health conditions. ${ }^{(12)}$

It was found in this study that the elderly lived with a range of biological, psychological and social changes that increased susceptibility to diseases and could even cause disability. The biological domain was the most affected, mainly due to the chronicity of the diseases. This fact was consistent with the result expected for elderly patients admitted to the hospital, who most often are fragile and have more complex care outcome. ${ }^{(22)}$

The psychological domain was less compromised. However, one should be aware of the need to assess for the presence of depressive symptoms in the elderly, because a study performed with the elderly at home showed that $23.9 \%$ had these symptoms and that they were associated with sociodemographic, health, and social behaviors of the elderly. ${ }^{(25)}$ 
The importance of resuming the humanist conception is emphasized in order to focus on the health-disease process in the elderly, in order to incorporate the assumptions of comprehensive care and to expand relationships between individuals and social structures involved in activities that promote, maintain and recover health. There must be a model that meets the care model, beyond the interests of the marketplace, which consists of the organization of actions to intervene in the health-disease process, articulating physical, technological and human resources in an attempt to achieve the resolution of health problems in a collective manner. ${ }^{(26-28)}$

It is necessary to rethink the responsibilities of the institutions facing the actual demands of the society and of the professionals in various areas of care for the elderly, families and communities, in order to introduce changes in the care model and social support equipment.

\section{Conclusion}

The results of this study demonstrated the importance of the INTERMED method because it enabled the multidisciplinary team to use it effectively for identifying the complexity of care, the biopsychosocial and health system vulnerability of the hospitalized elderly.

The knowledge of biopsychosocial factors, and of the health system, of the hospitalized elderly patient is important because it provides parameters that guide possible improvements in health practices, in programs, and in the implementation of public policies.

\section{Collaborations}

Gutierrez BAO contributed to the study design, analysis and interpretation of data, revising the intellectual content and approval of the version to be published. Silva HS collaborated in the development and statistical analysis of data, relevant critical revision of the intellectual content, and final approval of the version to be published. Shimizu HE contributed to the relevant critical revision of the intellectual content, and final approval of the version to be published.

\section{References}

1. Santos SS, Lopes MJ, Vidal, Silveira DA, Gauterio DP. [International classification of functioning, disability and health: use in nursing care for the elderly]. Rev Bras Enferm. 2013; 66(5):789-93. Portuguese.

2. Küchemann BA. Envelhecimento populacional, cuidado e cidadania: velhos dilemas e novos desafios. Soc Estado. 2012; 27(1):165-80.

3. Storti LB, Fabrício-Weber SCC, Kusumota L, Rodrigues RP, Marques S. [Frailty of elderly patients admitted to the medical clinic of an emergency unit at a general tertiary hospital]. Texto \& Contexto Enferm. 2013; 22(2):452-9. Portuguese.

4. Sochalski J, Jaarsma T, Krumholz HM, Laramee A, McMur JJ. What works in chronic care management: the case of heart failure. Health Affairs. 2009; 28(1):179.

5. Jack BW, Chetty VK, Anthony D, Greenwald JL, Sanchez GM, Johnson $A E$, et al. A reengineered hospital discharge program to decrease hospitalization. Ann Intern Med. 2009; 150(3):178-87.

6. Wild B, Lechner S, Herzog W, Maatouk I, Wesche D, Raum E et al. Reliable integrative assessment of health care needs in elderly persons: the INTERMED for the elderly (IM-E). J Psychosom Res. 2011;70(2):169-78.

7. Weber B, Fratezi FR, Suzumura EA, Gutierrez BA, De Negri Filho A, Ciampone MH. Tradução e adaptação transcultural do Interdisciplinary Medicine Instrument - INTERMED - método de avaliação biopsicossocial no Brasil. Rev Adm Hospitalar Inovação Saúde. 2012:9:87-98.

8. Stiefel F, Zdrojewski C, Bel Hadj F, Boffa D, Dorogi Y, So A, et al. Effects of a multifaceted psychiatric intervention targeted for the complex medically ill: a randomized controlled trial. Psychother Psychosom. 2008; 77(4):247-56.

9. Lobo E, Rabanaque MJ, Bellido ML, Lobo A. Reliability of INTERMED Spanish version and applicability in liver transplant patients: a crosssectional study. BMC Health Serv Res. 2011;11:160.

10. Kathol GR, Kunkel EJ, Weiner JS, McCarron RM, Worley LL, Yates LL, et al. Psychiatrists for medically complex patients: bringing value at the physical health and mental health/substance-use disorder interface. Psychosomatics. 2009; 50(2):93-107.

11. Jonge P, Huyse FJ, Rabanaque MJ, Suárez J, Lobo A. Early prediction of psychosocial intervention needs in pneumology patients after nurses' evaluation. Med Clin. 2008;131(19):731-6.

12. Perez M. A População idosa e o uso de serviços de saúde. Rev Hosp Univ Pedro Ernesto. 2008; 7(1):30-7.

13. Haddad MC, Bortoletto MS, Silva RS. [Amputation of inferior limbs of diabetics patients: analysis of hospitalization cost in public hospital]. Cienc Cuid Saúde. 2010; 9(1):107-13. Portuguese.

14. Gomes GA, Cintra FA, Batista FS, Neri AL, Guariento ME, Rosário de Souza ML, et al. [Elderly outpatient profile and predictors of falls]. Sao Paulo Med J. 2013; 131(1):13-8. Portuguese.

15. Sousa-Muñoz RL, Fernandes Junior ED, Nascimento DB, Garcia BB, Moreira IF. [Association between depressive symptomatology and hospital death in elderly]. J Bras Psiquiatr. 2013; 62(3):177-82. Portuguese. 
16. Andrade FB, Ferreira Filha MO, Dias MD, Silva AO, Costa IC, Lima EA, et al. [Promoting elderly mental health in basic care: community therapy contributions]. Texto \& Contexto Enferm. 2010;19(1):129-36. Portuguese.

17. Louvison M, Lebrão ML, Duarte YA, Santos JL, Malik AM, Almeida ES. [Inequalities in access to health care services and utilization for the elderly in São Paulo, Brazil]. Rev Saúde Pública. 2008; 42(4):733-40. Portuguese.

18. Brasil. Ministério do Planejamento, Orçamento e Gestão. Instituto Brasileiro de Geografia e Estatística. Indicadores sociais municipais: uma análise dos resultados do universo do Censo Demográfico. Brasília (DF): Ministério do Planejamento; 2010.

19. Carvalhais $M$, Sousa $L$. The quality of nursing home care to dependent elderly]. Saúde Soc. 2013; 22(1):160-72. Portuguese.

20. Pimenta GM, Carneiro da Costa MA, Gonçalves LH, Alvarez AM. [Profile of the caregiver of dependent elderly family members in a home environment in the City of Porto, Portugal]. Rev Esc Enferm USP. 2009; 43(3):809-14. Portuguese.

21. Tahan J, Carvalho AC. [Reflections of aged participating in the health promotion groups concerning the ageing and the quality of life].Saude Soc. 2010;19(4):878-88. Portuguese.

22. Estrella K, Oliveira CE, Sant'Anna AA, Caldas CP. [Screening for risk of hospitalization in the elderly: a study based on a single entry point in a health maintenance organization in Brazil] Cad. Saúde Pública. 2009; 25(3):507-12. Portuguese.

23. Lobo E, Stiefel F, Söllner W, Santabarbara J, Lobo A, Huyse F, Marcos G, Michaud L, Hohenberger W, Ludwig G. Care complexity, mood, and quality of life in liver pre-transplant patients. Clin Transplant 2013: 27: 417-25.

24. Tandjung R, Rosemann T, Badertscher N. Gaps in continuity of care at the interface between primary care and specialized care: General practitioners' experiences and expectations. Int J Gen Med. 2011; 4:773-8.

25. Borges LJ, Benedetti TR, Xavier AJ, D'Orsi E. [Associated factors of depressive symptoms in the elderly: EpiFloripa study]. Rev Saúde Pública. 2013; 47(4):701-10. Portuguese.

26. Matzer F, Wisiak UV, Graninger M, Söllner W, Stilling HP, GlawischnigGoschnik M, Lueger A, Fazekas C. Biopsychosocial health care needs at the emergency room: challenge of complexity. PLOS One. 2012;7(8):e41775

27. Brito TA, Fernandes MH, Coqueiro RS, Jesus CS. [Falls and functional capacity in the oldest old dwelling in the community]. Texto \& Contexto Enferm. 2013; 22(1):43-51. Portuguese.

28. Maiers MJ, Westrom KK, Legendre CG, Bronfort G. Integrative care for the management of low back pain: use of a clinical care pathway. BMC Health Serv Res. 2010, 10:298. 